\title{
EXPRESSION OF THE SONIC HEDGEHOG EMBRYONIC SIGNALLING PATHWAY COMPONENTS IN MATCHED PRE-TREATMENT AND RELAPSED SMALL CELL LUNG CANCER BIOPSIES
}

\author{
Viktors Kozirovskis ${ }^{1,2, \#, ~ E l i n n a ~ Z a n d b e r g a ~}{ }^{3}$, Melita Magone ${ }^{1}$, Gunta Purkalne ${ }^{1,2}$, \\ Aija Line $^{3}$, and Uldis Vikmanis ${ }^{2}$

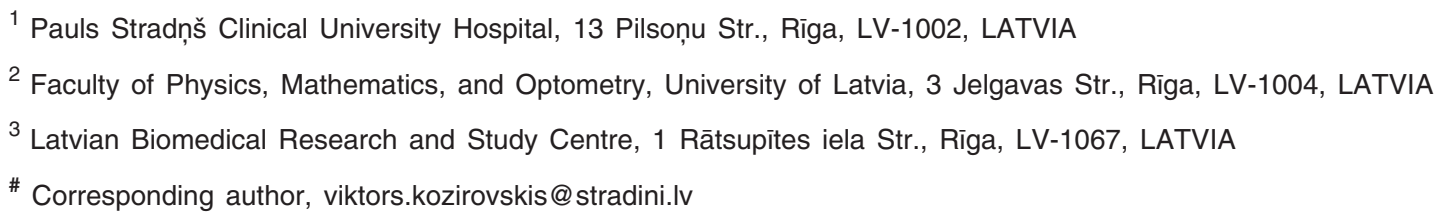

Communicated by Jānis Gardovskis

\begin{abstract}
Cancer stem cells may be responsible for tumour regrowth and acquisition of resistance in small cell lung cancer (SCLC). The Hedgehog pathway regulates survival and proliferation of tissue progenitor and stem cell populations, promoting the expression of stem cell related and proliferative genes. We evaluated the Sonic Hedgehog (Shh) embryonic signalling pathway in relapsed SCLC. Expression levels of Shh related genes GLI1, SMO, SUFU, PTCH1, HHIP, BCL2, BMI, ZEB1, ZEB2, N-MYC, Twist1 were analysed by $q R T-P C R$ in matched pre-treatment and relapsed tumour fresh frozen biopsies of three SCLC patients. Expression of each gene was compared using the paired samples t-test, as well as comparison of mean expression levels was done. Data were statistically interpreted using the MedCalc version 10.2.0.0 software. 2.9-fold lower mean mRNA expression of the major Hedgehog activation indicator GLI1 was observed in relapsed samples $(p=0.0529)$. Mean expression of six Shh inducible genes, PTCH1, HHIP, N-MYC, ZEB2, Twist1, ZEB1, was also downregulated by 2.6-, 2.2-, 1.9-, 1.8-, 1.2-, 1.1-fold, respectively $(\mathrm{p}=0.4252, \mathrm{p}=0.1268, \mathrm{p}=0.2480, \mathrm{p}=0.1169, \mathrm{p}=0.1480, \mathrm{p}=0.7595$, respectively). 1.8-fold mean expression decrease was found for Gli activator Smo $(p=0.4111)$. Only the Shh pathway inhibitor SUFU and two other examined Hedgehog signalling inducible genes BCL2 and BMI in relapsed SCLC showed 0.8-, 0.9-,and 0.8-fold increase of expression, respectively ( $\mathrm{p}=$ $0.3074, p=0.7921$, and $p=0.3822$, respectively). To our knowledge, this is the first report of comparison of Shh signalling in matched pre-treatment and relapsed SCLC biopsies. Our data show decreased activity for majority of Shh pathway components in relapsed SCLC, although difference did not reach statistical significance.
\end{abstract}

Keywords: relapsed SCLC, cancer stem cells, Sonic Hedgehog pathway, gene expression, matched biopsies.

\section{INTRODUCTION}

Small cell lung cancer is a malignant disease, where presence of a cancer stem cell (CSC) subpopulation is suggested by clinical practice. Standard chemotherapy may reduce tumour mass very effectively and even induce complete remission in the majority of patients (Okuno and Jett, 2002). Unfortunately, recurrence almost always occurs and virtu- ally no extensive-stage disease patients remain alive for five years (Jett et al., 2013). This can be explained by the survival of a small fraction of dormant and treatment-resistant CSC during initial chemotherapy and further repopulation of the tumour. The majority of cells, like CSC in recurrent tumours, acquire resistance to chemotherapy. One major characteristic feature of CSC is its ability to exclude Hoescht dye from the cell due to high expression of drug 
transporters like the $\mathrm{ABC}$ transporter family, including ABCB1 and ABCG2 (Goodell et al., 1996). Selection and further study of CSC therefore became possible in small cell lung cancer (SCLC) cell lines and mouse models within the so-called side population fraction (with poor Hoescht dye saturation). Many stemness and drug resistance associated genes were found to be overexpressed in SCLC CSC, as well as genes involved in the embryonic signalling pathways - Notch and Hedgehog (Salcido et al., 2010). The Hedgehog pathway activation was found in SCLC tumours (Watkins et al., 2003) and its blockade inhibited growth of SCLC tumour xenografts in mice (Vestergaard et al., 2006). Additionally, increased Hedgehog signalling was found to be associated with activation of neuroendocrine precursors within the airway epithelial compartment, which could be of importance in SCLC with its primitive neuroendocrine features (Zochbauer-Muller et al., 2002).

The aim of this study was to investigate and compare Sonic Hedgehog (Shh) embryonic signalling pathway activity in small cell lung cancer biopsies before and after acquisition of resistance. In this retrospective study we evaluated mRNA expression of key Shh pathway member genes in advanced stage SCLC samples before treatment and at progression of the disease.

The following genes were evaluated:

1) the major indicator of Hedgehog activation - positive pathway regulator and pathway transcriptional target Glioma-Associated Oncogene Homolog 1 (Gli1) (Katoh and Katoh, 2009a), as well as Gli activator Smoothened (Smo) (Gupta et al., 2010);

2) pathway inhibitor Suppressor Of Fused Homolog (SUFU) (Sabol et al., 2018), and

3) the most important genes inducible by Hedgehog signalling: pathway canonical negative feedback regulators Protein Patched Homolog 1 (PTCH1) and Hedgehog Interacting Protein (HHIP1) (Pietrobono et al., 2019), antiapoptotic B-Cell CLL/Lymphoma 2 (BCL2), CSC marker and epigenetic regulator BMI1 polycomb ring finger oncogene $(B M I)$, epithelial-to-mesenchymal transition inducers Zinc Finger E-Box Binding Homeobox 1 and 2 (ZEB1, ZEB2) (Katoh and Katoh, 2009a), drug resistance associated NMYC (Salcido et al., 2010) and direct transcriptional target of Gli1 - Twist Family BHLH Transcription Factor 1 (Twist1) (Kong et al., 2015).

\section{MATERIALS AND METHODS}

Patients and tissue samples. Pre-treatment tissue samples for the study were collected along with standard biopsies during fibrobronchoscopy (FBS) from patients who were diagnosed with advanced (stage III B and IV) SCLC at Pauls Stradiņš Clinical University Hospital between October 2010 and January 2014. Tissue specimens were submerged in RNAlater solution (Thermo Fisher Scientific, USA) and stored at $-20{ }^{\circ} \mathrm{C}$. The presence of tumour cells in the study samples was verified by cytological evaluation of a smear, which was obtained before placing the sample in RNAlater. All diagnoses were histologically confirmed as SCLC in standard biopsies by board-certified pathologists; the presence of tumour cells in study smear was done by a boardcertified cytologist. Pre-treatment biopsies from 20 SCLC patients were obtained and they were followed during treatment. At the moment of disease progression, repeated FBS and study biopsies of relapsed SCLC was done in five patients. Two patients were excluded from the analysis (one due to the lack of cytological confirmation of tumour cell presence in the pre-treatment study biopsy the other due to the bad RNA quality in the relapsed tumour biopsy). A small cohort of samples that was available for testing consisted of matched pre-treatment and relapsed SCLC biopsies from the same patient $(n=3)$.

Demographics and clinical characteristics of the studied patients and comparison of three patients, who had qualitative both pre-treatment and relapsed SCLC biopsies vs patients not included in paired gene expression analysis are shown in Table 1. Statistically significant age and ECOG differences were found between groups, while patients were comparable in terms of gender, disease stage, toxicity, received treatment, best response to therapy, disease progression type, and survival.

The study was approved by the Ethics Committee of the Institute of Experimental and Clinical Medicine, University of Latvia. The tissue samples were collected after written informed consent was obtained from the patients.

Preparation of tissue mRNA. Biopsy homogenisation was done by FastPrep®-24 Instrument and Lysing Matrix D (MP Biomedicals, USA) at $0.4 \mathrm{~m} / \mathrm{s}$ for 40 seconds. Total RNA was isolated using the MirVana total RNA Isolation Kit (Thermo Fisher Scientific, USA) and was treated with DNAse I (Thermo Fisher Scientific, USA) according to the manufacturer's protocol. RNA concentration and purity was quantified by a Nanodrop ND-100 spectrophotometer. cDNA was synthesised by random hexamer priming from 1 $\mu \mathrm{g}$ of total RNA by using the Revert Aid First Strand cDNA Synthesis kit (Thermo Fisher Scientific, MA, USA) according to the manufacturer's instructions.

Quantitative RT-PCR. Quantitative real-time PCR (qRT-PCR) was performed using $2 \mu \mathrm{l} 1: 10$ diluted cDNA reaction mixtures, ABSolute Blue TM SYBR green Low ROX (Thermo Fisher Scientific, USA) and ViiA 7 real-time PCR system (Applied Biosystems, Life Technologies, USA). Sequences of primers used in this study are available on request. To normalise the expression data, the normalisation factor was calculated for each cDNA from the expression values of the three most stable references genes (ACTB, LRP10, YWHAZ) selected among seven frequently used housekeeping genes by using geNorm software. All qRT-PCR experiments were performed in duplicate and the data were presented in graphs as means \pm standard deviation. 
Table 1. Characteristics of three patients with pre-treatment and relapsed SCLC biopsies vs patients not included in paired gene expression analysis. The comparison between groups was carried out by the Student's t-test or the Chi Square test, according to the type of variable

\begin{tabular}{|c|c|c|c|}
\hline Patient characteristics & $\begin{array}{l}\text { Patients included } \\
\text { in paired gene } \\
\text { expression } \\
\text { analysis }(n=3)\end{array}$ & \begin{tabular}{|} 
Patients NOT \\
included in paired \\
gene expression \\
analysis $(\mathrm{n}=17)$
\end{tabular} & $p$-value \\
\hline Gender & & & 0.348 \\
\hline Male & 3 & 13 & \\
\hline Female & 0 & 4 & \\
\hline Age & & & 0.037 \\
\hline Mean (range) & $60(49-77)$ & $56.9(47-70)$ & \\
\hline ECOG & & & 0.048 \\
\hline 0 & 2 & 1 & \\
\hline 1 & 0 & 7 & \\
\hline 2 & 1 & 7 & \\
\hline 3 & 0 & 2 & \\
\hline Stage & & & 0.565 \\
\hline III A & 0 & 2 & \\
\hline III B & 1 & 5 & \\
\hline IV & 2 & 10 & \\
\hline $\begin{array}{l}\text { Deviations of treatment } \\
\text { dosing/timing due toxicity }\end{array}$ & & & 0.212 \\
\hline none & 1 & 12 & \\
\hline present & 2 & 5 & \\
\hline Treatment received & & & 0.948 \\
\hline Chemotherapy only & 1 & 6 & \\
\hline $\begin{array}{l}\text { Chemotherapy and } \\
\text { radiation therapy }\end{array}$ & 2 & 11 & \\
\hline Best response & & & 0.093 \\
\hline $\mathrm{CR}$ & 0 & 2 & \\
\hline PR & 2 & 13 & \\
\hline SD & 0 & 2 & \\
\hline $\mathrm{PD}$ & 1 & 0 & \\
\hline Disease progression type & & & 0.075 \\
\hline local & 1 & 4 & \\
\hline distant & 0 & 8 & \\
\hline combined & 2 & 1 & \\
\hline NK & 0 & 2 & \\
\hline not progressed & 0 & 2 & \\
\hline \multicolumn{4}{|l|}{ Survival } \\
\hline Mean PFS (months) & 6.7 & 25.8 & 0.469 \\
\hline Mean OS (months) & 11 & 28.2 & 0.506 \\
\hline
\end{tabular}

SCLC, small cell lung cancer; CR, complete response; PR, partial response; SD, stable disease; PD, progressive disease; NK, not known; PFS, progression-free survival; OS, overall survival; $\mathrm{PD}$, progressive disease

Statistical analysis. The mRNA level of each Shh related gene was compared in the same patient matched pretreatment vs relapsed SCLC samples using the two-tailed paired samples t-test, as well as comparison of mean expression levels of each tested gene was done in all pretreatment vs relapsed samples with calculation of $95 \%$ confidence intervals. Data were statistically interpreted using MedCalc version 10.2.0.0 software. $p$ values of $<0.05$ were considered significant.

\section{RESULTS}

To our knowledge, this is the first report that compares expression of the Shh signalling pathway components in matched pre-treatment and relapsed SCLC biopsies. Our results show decreased activity of majority of Shh pathway components in the relapsed SCLC tumour tissues, although the differences did not reach statistical significance.

2.9-fold lower mean mRNA expression of the major Hedgehog activation indicator GLII was observed in relapsed SCLC biopsies when compared with matched pre-treatment biopsies, although the difference did not reached statistical significance $(p=0.0529,95 \% \quad \mathrm{CI}:-0.0002023$ to 0.000003115 , two-tailed paired samples t-test) (Fig. 1, Table 2).

Mean expression of six genes inducible by Hedgehog signalling - PTCH1, HHIP, N-MYC, ZEB2, Twist1, and ZEB1 was also downregulated by 2.6-, 2.2-, 1.9-, 1.8-, 1.2-, and 1.1-fold, respectively, in relapsed SCLC samples without a statistical significant difference $(p=0.4252, p=0.1268, p=$ $0.2480, p=0.1169$, $\mathrm{p} p=0.1480$, and $p=0.7595$, respectively) (Figs. 1 and 2, Table 2).

1.8-fold mean expression decrease was found in paired biopsies at relapse for Gli activator Smo with no statistically significant difference ( $p=0.4111)$ (Fig. 2, Table 2).

For relapsed SCLC, only Shh pathway inhibitor $S U F U$ and 2 examined Hedgehog signalling inducible genes - BCL2 and $B M I$ showed increase by $0.8-, 0.9-$ and 0.8 -fold, respectively, in their mean expression level, without statistically significant difference $(\mathrm{p}=0.3074, \mathrm{p}=0.7921$ and $\mathrm{p}=$ 0.3822 , respectively) (Fig. 3, Table 2).

\section{DISCUSSION}

To our knowledge, this is the first report that directly compares expression of the Shh signalling pathway components in matched pre-treatment and relapsed SCLC biopsies.

2.9 fold lower mean mRNA expression of the major Hedgehog activation indicator GLII was observed in relapsed SCLC biopsies compared to matched pre-treatment biopsies, although the difference did not reach statistical significance $(p=0.0529)$.

Mean expression of six genes inducible by Hedgehog signalling - PTCH1, HHIP, N-MYC, ZEB2, Twist1, and ZEB1 was also downregulated by 2.6-, 2.2-, 1.9-, 1.8-, 1.2and 1.1-fold, respectively, in relapsed SCLC, without statistically a significant difference $(p=0.4252, p=0.1268, p=$ $0.2480, p=0.1169, p=0.1480$, and $p=0.7595$, respectively), as well as 1.8-fold mean expression decrease in relapsed samples for Gli activator Smo, with no statistically significant difference $(p=0.4111)$.

For relapsed biopsies, only Shh pathway inhibitor $S U F U$ and the other two examined Hedgehog signalling inducible genes - BCL2 and BMI showed increase by $0.8-, 0.9-$, and 
Gli1

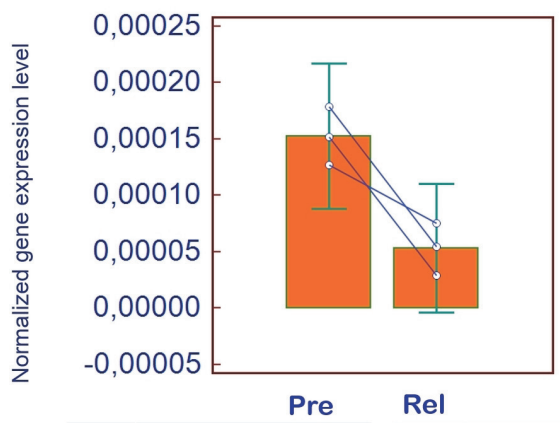

LC121 $0.000127038 \pm 0.000004607 \quad$ LC121R $0.000075173 \pm 0.000032693$ LC127 $0.000179067 \pm 0.000118971 \quad$ LC127R $0.000054643 \pm 0.000005748$ LC146 $0.000151824 \pm 0.000000007 \quad$ LC146R $0.000029327 \pm 0.000013569$

Two-tailed paired samples t-test: $p=0.0529,95 \%$ Cl: -0.0002023 to 0.000003115 HHIP

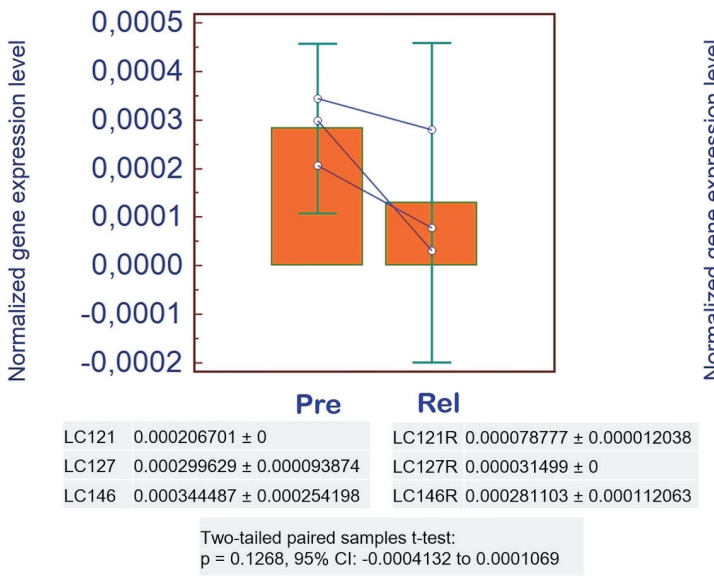

0.8-fold, respectively, in their mean expression level, without statistically significant difference $(p=0.3074, p=$ 0.7921 , and $p=0.3822$, respectively).

Cancer stem cells may be responsible for tumour initiation, regrowth and acquisition of resistance. Many studies have linked the aberrant hedgehog signalling to renewal and sur-
PTHC1

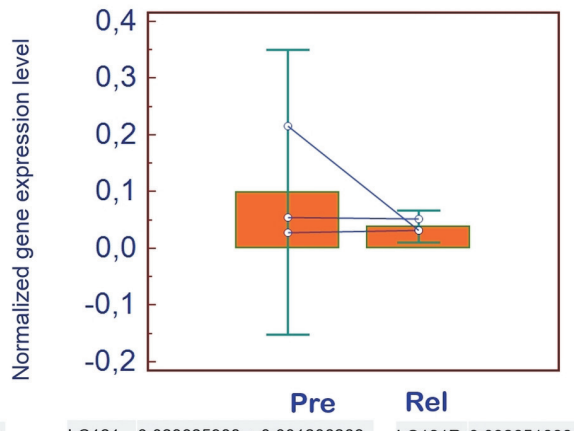

LC121 $0.028625988 \pm 0.001206266$ LC121R $0.032651666 \pm 0.003275214$ Fig. 1. Dot and line diagram $\begin{array}{llll}\text { LC127 } & 0.055043689 \pm 0.011726647 \quad \text { LC127R } 0.051743079 \pm 0.003699516\end{array}$ LC146 $0.215460534 \pm 0 \quad$ LC146R $0.032049930 \pm 0.000926679$

Two-tailed paired samples t-test: $p=0.4252,95 \% \mathrm{Cl}:-0.3246$ to 0.2028 NMYC

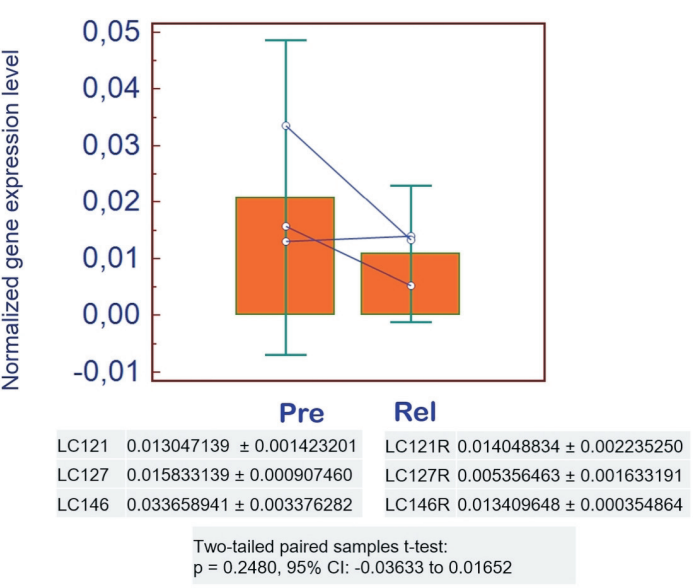
ene plotted connected by a line for the same SCLC patient pre-treatment (Pre) and relapsed (Rel) samples. Bars for means with $95 \%$ CI for the mean. Data presented in graphs are means obtained from experiments in duplicates \pm standard deviation. SCLC, small cell lung cancer; CI, confidence interval; Gli1, Glioma-Associated Oncogene Homolog 1; PTCH1, Protein Patched Homolog 1; HHIP1, Hedgehog Interacting Protein; $N-M Y C$, a member of the MYC family of transcription factors. vival of cancer stem cells in SCLC, thus making it a promising therapeutic target.

Preclinical research in SCLC is relying mainly on cell lines and xenografts, due to the lack of widely available tumour samples (Hamilton et al., 2012). However, it has been observed that establishment of SCLC cell line/xenograft leads

Table 2. Comparison of mean expression level of Shh related genes in pre-treatment vs relapsed samples

\begin{tabular}{l|l|c|c|c}
\hline \multirow{2}{*}{ Tested gene } & \multicolumn{3}{c|}{ Mean expression level in 3 SCLC pre-treatment vs relapsed samples } \\
\cline { 2 - 5 } & pre-treatment & $95 \%$ CI for the mean & relapsed & \multicolumn{2}{c}{$\begin{array}{c}\text { Estimated } \\
\text { difference }\end{array}$} \\
\hline Gli1 & 0.0001526 & 0.000088 to 0.0002173 & 0.00005305 & -0.000004 to 0.0001101 \\
PTCH1 & 0.09971 & -0.1515 to 0.3509 & 0.01099 to 0.06664 \\
HHIP1 & 0.0002836 & 0.000109 to 0.0004582 & 0.03881 & -0.0001989 to 0.0004598 \\
N-MYC & 0.02085 & -0.006934 to 0.04863 & 0.01094 & -0.001096 to 0.02297 \\
Smo & 0.01722 & -0.0130 to 0.04744 & 0.009398 & -0.01974 to 0.03854 \\
ZEB2 & 0.02419 & 0.01042 to 0.03795 & 0.01354 & 0.004276 to 0.0228 \\
Twist1 & 0.004609 & -0.0004286 to 0.009646 & 0.003798 & -0.002644 to 0.01024 \\
ZEB1 & 0.007191 & -0.001361 to 0.01574 & 0.006662 & 1.9 \\
BCL2 & 0.02301 & 0.0006755 to 0.04534 & 0.02509 & 0.004601 to 0.008722 \\
SUFU & 0.007723 & 0.004172 to 0.01127 & 0.009916 & -0.01966 to 0.06984 \\
BMI & 0.08249 & 0.0108 to 0.1542 & 0.09763 & 0.002686 to 0.01715
\end{tabular}

Shh, Sonic Hedgehog; SCLC, small cell lung cancer; CI, confidence interval; Gli1, Glioma-Associated Oncogene Homolog 1; PTCH1, Protein Patched Homolog 1; HHIP1, Hedgehog Interacting Protein; N-MYC, a member of the MYC family of transcription factors; Smo, Smoothened; ZEB1, ZEB2, Zinc Finger E-Box Binding Homeobox 1 and 2; Twist1, Twist Family BHLH Transcription Factor 1; BCL2, B-Cell CLL/Lymphoma 2; SUFU, Suppressor Of Fused Homolog; BMI, BMI1 polycomb ring finger oncogene 
SMO

$-0,02$

\section{Pre Rel}

LC121 $0.021589397 \pm 0.001195098 \quad$ LC121R $0.022888842 \pm 0.000370183$ $\begin{array}{lll}\text { LC127 } & 0.003468303 \pm 0.001272382 & \text { LC127R } 0.001595450 \pm 0.000608580\end{array}$ LC146 $0.026588872 \pm 0.012033562$ LC146R $0.003710934 \pm 0.000469816$ Two-tailed paired samples t-test:

Twist1
LC121 $0.005806505 \pm 0.001617827-$ LC121R $0.005579031 \pm 0.000303374$ LC127 $0.002267573 \pm 0.000406793$ LC127R $0.000822888 \pm 0.000024599$ LC146 $0.005752802 \pm 0.000739508 \quad$ LC146R $0.004992653 \pm 0.000481317$

$$
\text { Two-tailed paired samples t-test: }
$$

$\mathrm{p}=0.1480,95 \% \mathrm{Cl}:-0.002327$ to 0.000705

BCL2

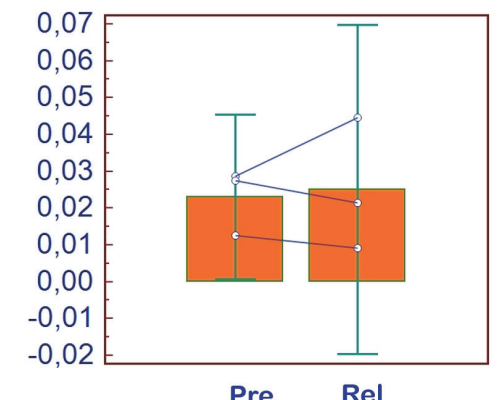

$\begin{array}{llll}\text { LC121 } & 0.012649696 \pm 0.000861131 & \text { LC121R } 0.009112428 \pm 0.000513348\end{array}$ $\begin{array}{llll}\text { LC127 } & 0.028770795 \pm 0.003152397 & \text { LC127R } 0.044614275 \pm 0.003887383\end{array}$ LC146 $0.027607673 \pm 0.002041380 \quad$ LC146R $0.021542361 \pm 0.003469204$ Two-tailed paired samples t-test: $p=0.7921,95 \% \mathrm{Cl}:-0.02769$ to 0.03186

BMI

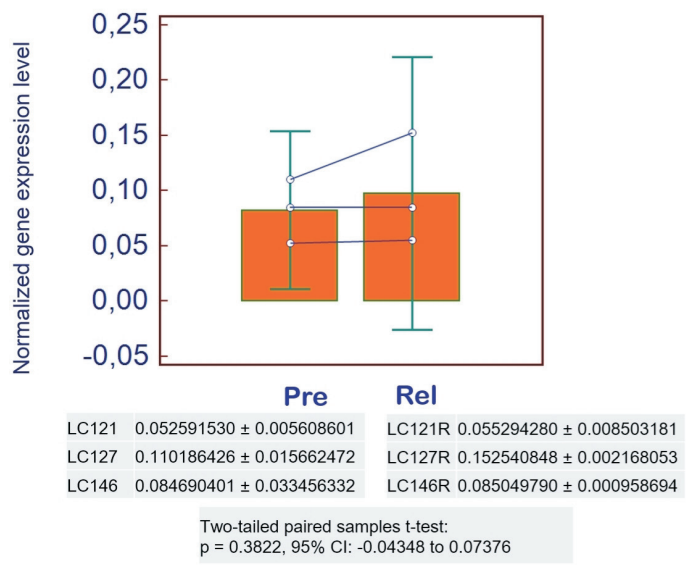

ZEB2

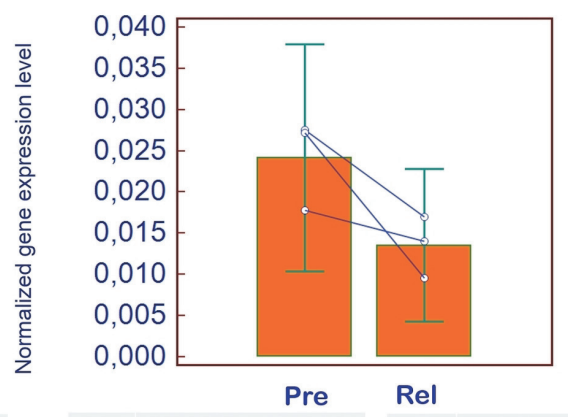

LC121 $0.027562301 \pm 0.000148595 \quad$ LC121R $0.016998815 \pm 0.001389826$ $\begin{array}{lll}\text { LC127 } & 0.027204291 \pm 0.001292875 & \text { LC127R } 0.009589461 \pm 0.000023505\end{array}$ $\begin{array}{lll}\text { LC146 } & 0.017788421 \pm 0.002890481 & \text { LC146R } 0.014028500 \pm 0.003650249\end{array}$

Two-tailed paired samples t-test:
$p=0.1169,95 \% \mathrm{Cl}:-0.02786$ to 0.006564 ZEB1

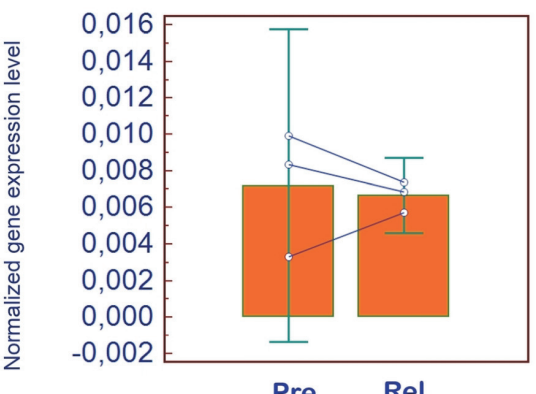

LC121 $0.009901585 \pm 0.000111612 \quad$ LC121R $0.007368567 \pm 0.000375439$ LC127 $0.008354126 \pm 0.000090085$ LC127R $0.006868277 \pm 0.000006735$ LC146 $0.003317516 \pm 0.001395528$ LC146R $0.005748559 \pm 0.000152126$$$
\begin{aligned}
& \text { Two-tailed paired samples t-test: } \\
& p=0.7595,95 \% \mathrm{Cl}:-0.007029 \text { to } 0.005971
\end{aligned}
$$

\section{SUFU}

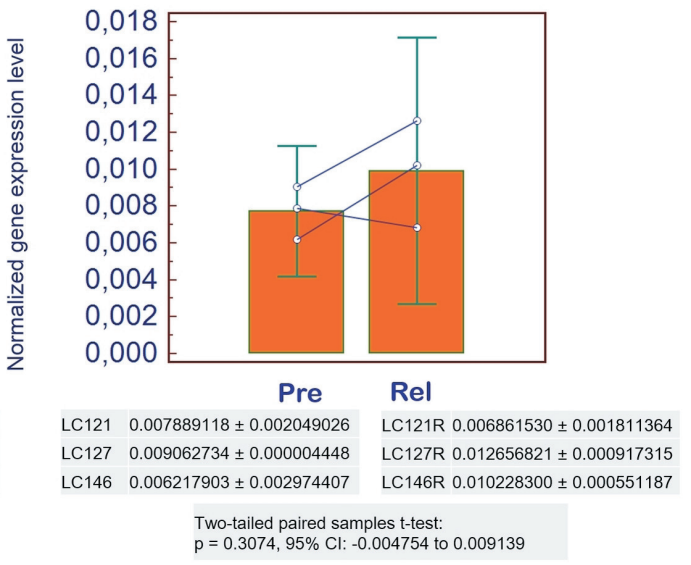

Fig. 2. Dot and line diagram with normalised gene expression levels of each Shh-related gene plotted as individual dots connected by a line for the same SCLC patient pre-treatment (Pre) and relapsed (Rel) samples. Bars for means with 95\% CI for the mean. Data presented in graphs are means obtained from experiments in duplicates \pm standard deviation. SCLC, small cell lung cancer; CI, confidence interval; Smo, Smoothened; ZEB1, ZEB2, Zinc Finger E-Box Binding Homeobox 1 and 2; Twist1, Twist Family BHLH Transcription Factor 1.
Fig. 3. Dot and line diagram with normalised gene expression levels of each Shh-related gene plotted as individual dots connected by a line for the same SCLC patient pre-treatment (Pre) and relapsed (Rel) samples. Bars for means with 95\% CI for the mean. Data presented in graphs are means obtained from experiments in duplicates \pm standard deviation. SCLC, small cell lung cancer; CI, confidence interval; BCL2, B-Cell CLL/Lymphoma 2; SUFU, Suppressor of Fused Homolog; BMI, $B M I 1$ polycomb ring finger oncogene 
to irreversible changes in gene expression (Daniel et al., 2009). Regarding Hedgehog signalling, it was shown previously that significantly higher mean GLII expression is present in SCLC tumour biopsies tissues compared to that in SCLC cell lines (Pedersen et al., 2003). Thus, caution should be taken when working with tumour-derived cell lines, as the expression and signalling may not reflect the in vivo situation. The advantage of this study is that mRNA expression of key Shh pathway members was evaluated in SCLC fresh biopsies (in vivo). To our knowledge, this is the first report of such analysis of Shh signalling pathway components in matched pre-treatment and relapsed SCLC samples.

Contrary to promising preclinical data that suggested a synergistic role between the canonical Shh pathway inhibitors and chemotherapy for targeting the chemoresistant subset of SCLC cells, no positive results from clinical trials evaluating activity of SMO inhibitors (Vismodegib, LDE-225, BMS-833923, and LY2940680) have been reported. One possible explanation of this failure in SCLC might be the non-canonical activation of Shh pathway key players. An example of ligand-independent GLII activation is GLII overexpression observed in the case of TP53 deficiency. Study of this mechanism showed that exposure of human medulloblastoma cell lines and Ptc-/- mouse embryonic fibroblasts to DNA damaging cytotoxic drugs induced concomitant expression of p53 and sequential downregulation of GLI1 through its p53-dependent ubiquitination and degradation (Mazzą et al., 2013). This dependency may be crucial in this particular lung cancer type because bi-allelic inactivation of TP53 and RB1 genes is observed nearly in all SCLC (George et al., 2015).

Other possible cause of increased ligand-independent Shh signalling is presence of activating mutations in RAS-RAFMEK, PI3K-AKT oncogenic signalling pathways or downregulation of the Notch pathway. Thus, oncogenic Hor N-RAS and AKT1 potentiate GLI1 function, by enhancing its transcriptional activity and nuclear localisation, and counteracting its cytoplasmic retention by SUFU in melanoma, prostate cancer and human glioma cells (Stecca et al., 2007). Similarly, loss of function of tumour suppressor PTEN (phosphatase and tensin homolog deleted on chromosome 10), an endogenous inhibitor of AKT, will lead to increased transcriptional activity of GLII. PTEN alterations can be found in 10-18\% of SCLC tumours (Yokomizo et al., 1998).

Another oncogene that was found to activate GLII independently from Shh ligand-mediated signalling is $C-M Y C$. It is frequently overexpressed in both SCLC and non-small cell lung cancer (NSCLC) (Wistuba et al., 2001). C-MYC directly binds to the GLII promoter and activates its transcription. Inhibition of C-MYC by small molecule inhibitors downregulates GLII mRNA and induces cell death in Burkitt lymphoma cells (Yoon et al., 2013).

While KRAS/AKT aberrant activation is a rare event in SCLC (Maitra et al., 2001; Wakuda et al., 2014; Yamamoto et al., 2008; Kodaz et al., 2016), Notch pathway signalling was found to be downregulated in $77 \%$ of 110 SCLC clinical tumour specimens, among which Notch family genomic alterations were found in $25 \%$ of cases (George et al., 2015). As Notch signals downregulate GLI1 expression via HES/HEY family members (Katoh and Katoh, 2009b), increased Shh signalling is possible in this case. Additional studies found reduced tumour formation, metastatic capability, cell cycle inhibition, and reduced neuroendocrine markers with Notch activation, thus demonstrating Notch as a tumour suppressor in SCLC (Hassan et al., 2014). One discovered mechanism of Notch pathway downregulation is overexpression of its inhibitor DLL3, which enhances endosomal/lysosomal degradation of both activatory Notch single-pass transmembrane receptors and membrane-bound ligand DLL1 (Chapman et al., 2011; Serth et al., 2015).

Considering multiple possible non-canonical Shh signalling interactions, our finding with lower (although statistically non-significant) GLII expression in relapsed SCLC samples when compared to matched pre-treatment biopsies might reflect the further increasing dysregulation of different signalling pathways and/or epigenetic mechanisms. In this case, accumulation of additional genetic/epigenetic changes over time decreases initially high GLI1 levels, which is characteristic for SCLC tumour biopsies and may be explained by a few critical genetic alterations like the frequently observed TP53 deficiency or downregulated Notch pathway signalling.

A possible limitation of the study might be the inclusion of primary resistant patients in the analysis. One patient did not respond to specific therapy, thus suggesting that resistance-associated changes were already present in the pre-treatment sample.

This study was the first attempt to solve the problem of notable lack of paired samples of newly diagnosed and recurrent SCLC. Unfortunately, only five patients from 20 had undergone FBS re-biopsy of their progressed tumour and only three qualitative matched paired samples were obtained. The main causes of such a low re-biopsy rate were distant disease progression only and refusal of patients to undergo a repeated invasive procedure. An issue was also the small size of biopsy samples and exclusion of a significant part of study patients from analysis due to lack of cancer cells in a biopsy.

Our data show decreased activity of the majority of Shh pathway components in the relapsed SCLC tumour tissues, although the differences did not reach statistical significance.

Thus, the activation of Shh signalling might not be a universal mechanism for SCLC relapse and resistance development.

Due to the small number of patients in this study, generalisation of our results is questionable. A longer period of time 
for tissue sample collection or inclusion of additional centres in the tissue collection programme may solve this problem.

\section{ACKNOWLEDGMENTS}

The authors would like to thank Dr. Romalda Grigalinoviča for her extra work while being study dedicated cytologist in this project.

\section{REFERENCES}

Chapman, G., Sparrow, D. B., Kremmer, E., Dunwoodie, S. L. (2011). Notch inhibition by the ligand DELTA-LIKE 3 defines the mechanism of abnormal vertebral segmentation in spondylocostal dysostosis. Hum. Mol. Gen., 20 (5), 905-916.

Daniel, V. C., Marchionni, L., Hierman, J. S., Rhodes, J. T., Devereux, W. L., Rudin, C. M., Yung, R., Parmigiani, G., Dorsch, M., Peacock, C. D., Watkins, D. N. (2009). A primary xenograft model of small-cell lung cancer reveals irreversible changes in gene expression imposed by culture in vitro. Cancer Res., 69 (8), 3364-3373.

George, J., Lim, J. S., Jang, S. J., Cun, Y., Ozretić, L., Kong, G., Leenders, F., Lu, X., Fernindez-Cuesta, L., Bosco, G. et al. (2015). Comprehensive genomic profiles of small cell lung cancer. Nature, 524 (7563), 47-53.

Goodell, M. A., Brose, K., Paradis, G., Conner, A. S., Mulligan, R. C. (1996). Isolation and functional properties of murine hematopoietic stem cells that are replicating in vivo. J. Exper. Med., 183 (4), 1797-1806.

Gupta, S., Takebe, N., Lorusso, P. (2010). Targeting the Hedgehog pathway in cancer. Ther. Adv. Med. Oncol., 2 (4), 237-250.

Hamilton, G., Ulsperger, E., Geissler, K., Olszewski, U. (2012). Therapy-induced changes of gene expression in a matched pair of small cell lung cancer (SCLC) cell lines. J. Cancer Ther., 3, 442-451.

Hassan, W. A., Yoshida, R., Kudoh, S., Hasegawa, K., Niimori-Kita, K., Ito, T. (2014). Notch1 controls cell invasion and metastasis in small cell lung carcinoma cell lines. Lung Cancer (Amsterdam), 86 (3), 304-310.

Jett, J. R., Schild, S. E., Kesler, K. A., Kalemkerian, G. P. (2013). Treatment of small cell lung cancer: Diagnosis and management of lung cancer, 3rd ed: American College of Chest Physicians evidence-based clinical practice guidelines. Chest, 143 (5 Suppl), e400S-e419S.

Katoh, Y., Katoh, M. (2009a). Hedgehog target genes: Mechanisms of carcinogenesis induced by aberrant hedgehog signaling activation. Curr. Mol. Med., 9 (7), 873-886.

Katoh, Y., Katoh, M. (2009b). Integrative genomic analyses on GLI1: positive regulation of GLII by Hedgehog-GLI, TGFbeta-Smads, and RTK-PI3K-AKT signals, and negative regulation of GLII by Notch-CSLHES/HEY, and GPCR-Gs-PKA signals. Int J Oncol. 35 (1), 187-92.

Kodaz, H., Tažtekin, E., Erdošan, B., Hacżbekirošlu, Ż., Tozkżr, H., Gürkan, H., Türkmen, E., Demirkan, B., Uzunošlu, S., Ēiēin, Ż. (2016). KRAS Mutation in small cell lung carcinoma and extrapulmonary small cell cancer. Balkan Med. J., 33 (4), 407-410.

Kong, Y., Peng, Y., Liu, Y., Xin, H., Zhan, X., Tan, W. (2015). Twist1 and Snail link Hedgehog signaling to tumor-initiating cell-like properties and acquired chemoresistance independently of ABC transporters. Stem Cells (Dayton, Ohio), 33 (4), 1063-1074.

Maitra, A., Tascilar, M., Hruban, R. H., Offerhaus, G. J., Albores-Saavedra, J. (2001). Small cell carcinoma of the gallbladder: A clinicopathologic, immunohistochemical, and molecular pathology study of 12 cases. Amer. J. Surg. Pathol., 25 (5), 595-601.

Mazzà, D., Infante, P., Colicchia, V., Greco, A., Alfonsi, R., Siler, M. Antonucci, L., Po, A., De Smaele, E., Ferretti, E. et al. (2013). PCAF ubiquitin ligase activity inhibits Hedgehog/Gli1 signaling in p53-dependent response to genotoxic stress. Cell Death Differ., 20 (12), 1688-1697.

Okuno, S. H., Jett, J. R. (2002). Small cell lung cancer: Current therapy and promising new regimens. Oncologist, 7 (3), 234-238.

Pedersen, N., Mortensen, S., Sørensen, S. B., Pedersen, M. W., Rieneck, K., Bovin, L. F., Poulsen, H. S. (2003). Transcriptional gene expression profiling of small cell lung cancer cells. Cancer Res., 63 (8), 1943-1953.

Pietrobono, S., Gagliardi, S., Stecca, B. (2019). Non-canonical Hedgehog Signaling Pathway in cancer: Activation of GLI transcription factors beyond smoothened. Frontiers Gen., 10, 556.

Sabol, M., Trnski, D., Musani, V., Ozretić, P., Levanat, S. (2018). Role of GLI transcription factors in pathogenesis and their potential as new therapeutic targets. Int. J. Mol. Sci., 19 (9), 2562.

Salcido, C. D., Larochelle, A., Taylor, B. J., Dunbar, C. E., Varticovski, L. (2010). Molecular characterisation of side population cells with cancer stem cell-like characteristics in small-cell lung cancer. Brit. J. Cancer, 102 (11), 1636-1644

Serth, K., Schuster-Gossler, K., Kremmer, E., Hansen, B., Marohn-Köhn, B., Gossler, A. (2015). O-fucosylation of DLL3 is required for its function during somitogenesis. PloS One, 10 (4), e0123776.

Stecca, B., Mas, C., Clement, V., Zbinden, M., Correa, R., Piguet, V., Beermann, F., Ruiz i Altaba, A. (2007). Melanomas require HEDGEHOG-GLI signaling regulated by interactions between GLI1 and the RAS-MEK/AKT pathways. Proc. Nat. Acad. Sci. USA, 104 (14) 5895-5900.

Vestergaard, J., Pedersen, M. W., Pedersen, N., Ensinger, C., Tümer, Z., Tommerup, N., Poulsen, H. S., Larsen, L. A. (2006). Hedgehog signaling in small-cell lung cancer: Frequent in vivo but a rare event in vitro. Lung Cancer (Amsterdam), 52 (3), 281-290.

Wakuda, K., Kenmotsu, H., Serizawa, M., Koh, Y., Isaka, M., Takahashi, S., Ono, A., Taira, T., Naito, T., Murakami, H. et al. (2014). Molecular profiling of small cell lung cancer in a Japanese cohort. Lung Cancer (Amsterdam), 84 (2), 139-144.

Watkins, D. N., Berman, D. M., Burkholder, S. G., Wang, B., Beachy, P. A., Baylin, S. B. (2003). Hedgehog signalling within airway epithelial progenitors and in small-cell lung cancer. Nature, 422 (6929), 313-317.

Wistuba, I. I., Gazdar, A. F., Minna, J. D. (2001). Molecular genetics of small cell lung carcinoma. Seminars Oncol., 28 (2 Suppl 4), 3-13.

Yamamoto, H., Shigematsu, H., Nomura, M., Lockwood, W. W., Sato, M., Okumura, N., Soh, J., Suzuki, M., Wistuba, I. I., Fong, K. M. et al. (2008). PIK3CA mutations and copy number gains in human lung cancers. Cancer Res., 68 (17), 6913-6921.

Yokomizo, A., Tindall, D. J., Drabkin, H., Gemmill, R., Franklin, W., Yang, P., Sugio, K., Smith, D. I., Liu, W. (1998). PTEN/MMAC1 mutations identified in small cell, but not in non-small cell lung cancers. Oncogene, 17 (4), 475-479.

Yoon, J. W., Gallant, M., Lamm, M. L., Iannaccone, S., Vieux, K. F., Proytcheva, M., Hyjek, E., Iannaccone, P., Walterhouse, D. (2013). Noncanonical regulation of the Hedgehog mediator GLI1 by c-MYC in Burkitt lymphoma. Mol. Cancer Res., 11 (6), 604-615.

Zochbauer-Muller, S., Gazdar, A. F., Minna, J. D. (2002). Molecular pathogenesis of lung cancer. Annu. Rev. Physiol., 64, 681-708. 


\section{SONIC HEDGEHOG EMBRIOĢENĒZI REGULĒJOŠĀ SIGNĀLCEL̨A KOMPONENTU EKSPRESIJA SĪKŠŪNU PLAUŠU VĒŽA}

PACIENTU PIRMSTERAPIJAS' UN RECIDĪVA PĀRA BIOPSIJĀS

Vēža cilmšūnas var būt par pamatu sīkšūnu plaušu vēža (SŠPV) recidīvam un rezistences attīstībai. Hedgehog signālceľ̦̌ regulē vairākus ar cilmšūnām un proliferāciju saistītus gēnus, tādējādi veicinot cilmšūnu un audu progenitoro šūnu izdzīvošanu un proliferāciju. Mēs izvērtējām Sonic Hedgehog (Shh) embrioǵenēzi regulējošo signālceḷu recidivējošā SŠPV. Izmantojot reālā laika kvantitatīvo $q R T-P C R$, tika analizēti ekspresijas līmeņi Shh saistītiem gēniem GLI1, SMO, SUFU, PTCH1, HHIP, BCL2, BMI, ZEB1, ZEB2, N-MYC, Twist1 trīs SŠPV pacientu audzēju svaigi saldēto pāra biopsiju paraugos, kas ņemti pirms terapijas un recidīva laikā. Katra gēna ekspresijas līmeņi saistītajām paraugkopām tika salīdzināti, izmantojot Stjūdenta t-testu, kā arī tika salīdzināti vidējie ekspresijas līmeņi. Datu statistiskā analīze veikta, izmantojot MedCalc 10.2.0.0 versijas programmu. Recidīva paraugos bija 2,9 reizes zemāka $(p=0,0529)$ vidējā mRNS ekspresija galvenajam Hedgehog signālceḷa aktivitātes indikatoram GLIl. Arī sešu Hedgehog signālcẹ̦a inducējamo gēnu $-P T C H 1, H H I P, N-M Y C$, ZEB2, Twist1, ZEB1 - vidējā ekspresija bija attiecīgi zemāka 2,6, 2,2, 1,9,1,8,1,2, 1,1 reizes (ar attiecīgu $p=0,4252, p=0,1268, p=$ $0,2480, p=0,1169, p=0,1480, p=0,7595)$. 1,8 reizes zemāka vidējā ekspresija bija konstatēta Gli aktivatoram Smo $(p=0,4111)$. Attiecīgi $0,8,0,9$ un 0,8 reizes augstāka vidējā ekspresija recidivējošā SŠPV (ar attiecīgu $p=0,3074, p=0,7921$ un $p=0,3822$ ) bija vienīgi signālceḷa inhibitoram $S U F U$ un 2 citiem izmeklētiem Hedgehog signālcę̣a inducējamiem gēniem BCL2 un BMI. Pēc mums pieejamās informācijas, šis ir pirmais ziṇojums, kas salīdzina Shh signālceḷa ekspresiju SŠPV pirmsterapijas un recidīva pāra biopsijās. Pētījumā iegūtie rezultāti norāda uz Shh signālceḷa komponentu samazinātu aktivitāti recidivējošā SŠPV, kaut starpība nav sasniegusi statistisku ticamību. 